\title{
Analysis of $\mathrm{P4}$ receptors polymorphisms in the development of breast cancer: $A$ study of Southern Punjab (Pakistan)
}

\author{
Sobia Sadia ${ }^{1}$, Rehan Sadiq Shaikh ${ }^{1}$, Nabeela Tariq ${ }^{2}$ and Tasleem \\ Kausar $^{3 *}$ \\ 1. Institute of Molecular Biology and Biotechnology, Bahauddin Zakariya University, Multan, Pakistan \\ 2. Department of Zoology, Sardar Bahadur Khan Women University, Quetta, Pakistan \\ 3. Department of Zoology, Government Sadiq College Women University, Bahawalpur, Pakistan \\ *Corresponding author's email: tasleem.kausar@gscwu.edu.pk
}

\section{Citation}

Sobia Sadia, Rehan Sadiq Shaikh, Nabeela Tariq and Tasleem Kausar. Analysis of P4 receptors polymorphisms in the development of breast cancer: A study of Southern Punjab (Pakistan). Pure and Applied Biology. Vol. 11, Issue 1, pp181-190. http://dx.doi.org/10.19045/bspab.2022.110020

\begin{tabular}{|c|c|c|c|}
\hline Received: 30/03/2021 & Revised: 20/05/2021 & Accepted: $21 / 05 / 2021$ & Online First: $23 / 05 / 2021$ \\
\hline
\end{tabular}

\section{Abstract}

Contrary to reports with conflicting results, progesterone is suspected to play an important role in the development of tumours in the women. A research work was conducted to assess the significance of PGR SNPs (progesterone receptor) polymorphisms in the progression of breast cancer in southern Punjab (Pakistan). Because of the lack of detailed analysis of $P G R$ gene variations in the Pakistani community, two variants PROGINS and +331 G/A were selected. The Radiology and Oncology Department at Nishtar Medical College and Hospital in Multan, Pakistan, assisted researchers for enrolling 100 invasive breast cancer patients and one hundred and fifteen healthy controls. DNA was isolated using a non-organic method, and two SNPs were analysed by (Polymerase Chain Reaction Restriction Fragment length polymorphism) PCR-RFLP. Study participants were examined for their clinical/family history, demographic factors (e.g. age, Menopause, age of menopause, marital status, gestation status, history of memory carcinoma, cigarette consumption, and chemical exposure), and other variables being related to specific symptomatology. The wild type allele of both SNPs was observed with highest prevalence in patients and control individuals followed by heterozygous allele while homozygous mutant allele was present in least numbers. Chi square statistics for PROGINS showed $(\mathrm{p}=0.448)$ an evidence of non-significant association while $+331 G / A$ variant $(\mathrm{p}=0.004)$ showed an inverse association with breast cancer risk. Further genetic studies using progesterone receptors for breast cancer risk can use our results as a database.

Keywords: Breast Cancer; Menopause; Progesterone; Progins

\section{Introduction}

It affects more than one million people each year, mostly women, and is the main reason of death in females. Our country is bearing a double load of disease due to substantial incidence of cancer and increasing tendency in risk factors like smoking and alcohol consumption [1]. According to a study, every ninth woman in Pakistan is at risk of developing breast carcinoma. Age, menopause, alcohol, sex, race, with already affected persons in the family, reproductive condition, living standard, iodine deficient level, high-cholesterol food intake, overweight, smoking, UV rays, hormones disturbance and work load are some of the known risk factors predisposing population towards breast carcinoma $[2,3]$. Molecular 
analysis can help to generate useful data for public health management since the prevalence and death ratio because of this disease are very alarming in our country and there is no population-based registries data available.

In addition to the environmental factors, genetic causes also have significant contribution in enhancement of chances of cancer development. There are a number of genes associated with breast cancer, including estrogen receptor (ESR), progesterone receptor $(P R), \quad$ GSTT1, GSTM1, GSTO2, GSTP1, and XPD.

This steroid is an essential structural constituent of the testosterone. It resides in the cells of the endocrine glands, testicles, brain, and placenta and undergoes a variety of biochemical processes during gestation, characterized with multiple stimulation and inhibition functions. In conjunction with estrogen, it is associated with the progression of pregnancy, adolescence, mammary ductal branching and differentiation of lobuloalveolar branches in a pregnant female $[4,5]$.

Seven variables along with two promoter variants $(+44 C / T$ and $+331 G / A)$, four single nucleotide polymorphisms (p.Ser334Thr, p.Gly393Gly, p.Val660Leu $\&$ p.His770His), and an insertion in noncoding region were studied previously in different population with conflicting results [6]. Val660Leu, His770His, Ser334Thr and Alu insertion in intron 7 , these three variables form the PROGINS allele complex [7]. Because of linkage disequilibria, all polymorphisms have substantially similar genotype.

PROGINS allele does not tend to be involved with any impacts on the biological activity of progesterone receptors. Nevertheless, the PROGINS SNP has an association with an elevated breast, ovarian, and endometrial carcinoma potential. [8,9], with some studies showing non-significant association between PROGINS and cancer susceptibility. Other studies showed that women who have both alleles of the PROGINS gene are at a greater risk of getting ovarian carcinoma with lower breast cancer risk [10-12].

Similar conflicting studies have been stated regarding the relationship of $+331 G>A$ variant with breast cancer. Contradictory data exist regarding the involvement of progesterone receptor genes in cancer growth through in vitro research indicating that it may increase and decrease the process of cell proliferation or have no role at all $[13,14]$. The PROGINS and +331 G/A variations were chosen on account of their relation with endometrial, uterine and breast carcinomas showing conflicting findings in various communities.

\section{Objectives}

It was the purpose of this research work to ascertain whether progesterone polymorphisms were present among Pakistani females who progressed breast cancer, and to compare the frequency of polymorphisms identified in Pakistan with that observed in other communities.

\section{Materials and Methods Sample collection}

A research work was approved by the Institutional Review Boards (IRB) at Nishtar Medical College and Hospital in Multan, Pakistan and the Institute of Molecular Biology and Biotechnology at Bahauddin Zakariya University, Multan, Pakistan. Before taking blood samples from the control subjects and each case, there was a written informed agreement. All medical and demographical information was collected with the help of a special questionnaire (menstrual/breast feeding histories, menarche, menopause, use of birth control pills, family history, chemical exposure and tobacco history). The research identified and enrolled over 100 women aged 15 to 65 who had invasive breast cancer. We arbitrarily selected 115 healthy persons without any record of cancer in family from Southern Punjab (Multan, Dera Ghazi Khan, Rajan Pur, Layyah and Lodhran districts) Pakistan.

\section{Molecular exploration}

A blood sample was collected for DNA analysis by using a non-organic protocol 
[15]. Analysis of Val660Leu and $+331 \mathrm{G}>\mathrm{A}$, SNPs was performed by using PCR restriction fragment length polymorphism (PCR-RFLP) method using forward and reverse primers. Amplification of Val660Leu and $+331 \mathrm{G}>\mathrm{A}$ variants of $P G R$ gene was carried out by using a nested PCR approach. Amplified products of PROGINS (138bp) and +331G>A (206 bp) polymorphisms were restricted with Brs1 and NIaIV (Fermentas, USA) respectively and were studied on $1.5 \%$ agarose gel. Results for polymorphisms of PROGINS were determined by observing the restriction pattern i.e. homozygous wild type $(+/+)$ has a fragment of $138 \mathrm{bp}$, heterozygous (+/-) has three fragments 115 , 95 and 23 bp and homozygous mutant (-/-) has two fragments of 115 and $23 \mathrm{bp}$.

\section{Results}

One hundred females diagnosed with breast cancer from Nishtar Medical College and Hospital and one hundred and fifteen control individuals enrolled from different areas of Punjab were included in the study. Each case and control subject was between 15 and 65 years old. Several other factors were also used to analyze what effect they had on the phenotype, such as the occurrence of menopause and the age of menopause, marriage, pregnancy, history of breast carcinoma, the influence of smoking, and chemicals.

In the study, there were about half menopausal women and at least half premenopausal women with breast cancer. Menopausal age ranged between 28-58 years. About 97 percent of patients were married and breast cancer was diagnosed mostly between 36-45 years of age. In patients, only 16 had a family history, whereas all the others had an isolated growth. Only 4 of the breast cancer patients had smoked cigarettes, and 16 of them had been exposed to pesticides (Table 1). PROGINS and +331G/A SNPs were analyzed with PCR-RFLP technique. A fragment of the progesterone receptor gene of $138 \mathrm{bp}$ was amplified by primers designed for the PROGINS SNP (Fig. 1),
The amplification of $+331 \mathrm{G}>\mathrm{A}$ allele was achieved by exploiting a fragment of 206 base pairs. Wild type allele $(+331 \mathrm{GG})$ produces two segments of 149 and 57bp and heterozygous alleles of 206 and $149 \mathrm{bp}$; mutated allele $(+331 \mathrm{AA})$ produces only one fragment of $206 \mathrm{bp}$ due to absence of any NIaIV restriction site.

\section{Statistical analysis}

For the purpose of determining the relationships between all variables, the frequencies were calculated. HardyWeinberg equilibrium in control samples was checked by applying Chi-square test. The development of breast tumor due to PROGINS and +331G/A variants was checked by Pearson's Chi-square applying in SPSS. Based on a probability of greater than 0.05 , an association was established. whereas primers for $+135 \mathrm{G} / \mathrm{A}$ result in 206 bp of a gene fragment, as shown by ethidium bromide stained gel (Fig. 2). Majority of the patients $(22.3 \%)$ were between 36-45 years of age, with maximum frequency of breast cancer $(x 2=50.26 ; \mathrm{df}=$ $4 ; \mathrm{P}<0.0001)$. Based on statistical analysis, it was found that menopause made a significant impact on breast cancer incidences $(\mathrm{P}<0.0001$; Table 1$)$.

It is depicted by the results that menopausal women have 5 to 6 times greater risk of carcinoma development $(22.3 \% ; \mathrm{x} 2=$ $27.72 ;$ d.f. $=1 ; \mathrm{P}<0.0001)$ when matched with the women of premenopausal condition $(8.4 \%)$. Moreover, there is a great effect of age of menopause (x2=29.41; d.f. $=3 ; \mathrm{P}<0.0001)$ on breast carcinoma development in local community. The menopause age was observed between 36 45 years for $15.8 \%$ of the cancer patients. The findings furthermore showed that the maximum cancer rate in most of our patients $(20.5 \%)$ is between $36-45$ years of age. This study suggests that cancer predisposition is also related to the patient's age, menopausal status, and the age at cancer diagnosis. and Interesting to note, these risk factors show almost the same correlation over the course of the same time period. Furthermore, breast cancer was 
significantly more prevalent in those with a family history of cancer as compared to control samples $(\mathrm{x} 2=19.87$; d.f. $=1 ; \mathrm{P}<$ $0.0001)$. But other factors such as marital status, the age at the first pregnancy, the total number of pregnancies, breastfeeding, maternal smoking, and pesticide prior exposure did not indicate a significant association with breast cancer susceptibility (Table 1).

Logistic regression analysis of causative agents like pre-menopause/menopause with breast cancer was implemented. There appeared to be a surprising correlation between the middle-aged women (36-45 years) and the likelihood of breast cancer ( $\mathrm{t}$ $=0 ; \mathrm{B}=-5.14 ;$ d.f. $=213 ; \mathrm{P}<0.0001)$. Breast feeding enhances the chances of developing cancer in premenopausal females by a significant value $(\mathrm{t}=0 ; \mathrm{B}=$ 2.31 ; d.f. $=213 ; \mathrm{P}=0.021$ ).

Premenopausal women who feed their kids have a higher risk of developing cancer. Although, no significant association was found between PROGINS and premenopausal women $(\mathrm{t}=0 ; \mathrm{B}=3.32$; d.f. $=213 ; \mathrm{P}=0.60)$, significant associations for cancer susceptibility were observed with $+331 \mathrm{G} / \mathrm{A}$ during pre-menopause but not with $+331 \mathrm{G} /$ A during menopause $(\mathrm{t}=0 ; \mathrm{B}=$ -6.24 ; d.f. $=213 ; \mathrm{P}=0.045)$. So, it can be concluded that pre-menopause has an impact on polymorphism $+331 \mathrm{G} / \mathrm{A}$ which is associated with cancer development (Table 2).

There were no significant associations between PROGINS genotypes and phenotypes of breast cancer for either SNP ( $\mathrm{x} 2=1.6 ; \mathrm{df}=2 ; \mathrm{P}>0.05$; Table 3$)$, as homozygous wild type was observed in $69 \%$ of the patients with very nearly same frequency in healthy group $(72.2 \%)$. The percentage of heterozygous allele of the PROGINS polymorphism was $29 \%$ and $27 \%$ in patients and normal individuals of total samples. Homozygous mutant allele of PROGINS was observed in only $2 \%$ of the case samples. Likewise, it is more frequent to have wild-type alleles $(\mathrm{F}=0.84)$ in PROGINS than mutant alleles $(\mathrm{F}=0.16)$.
With the wild-type genotype being more prevalent than other genotypes both in healthy individuals and in those affected with breast cancer showing non-significant association with breast cancer development, so it can be demonstrated that PROGINS variation may has no important function in cancer predisposition. On the other hand, Breast cancer risk was inversely related to the polymorphism $+331 \mathrm{G} / \mathrm{A}(\mathrm{x} 2=9.13$; d.f. $=2 ; \mathrm{P}=0.004)$. The frequency of wild type allele of $+331 \mathrm{G} / \mathrm{A}(93 \%)$ was higher than heterozygous allele $(3.3 \%)$. The mutant allele was not noticed in any of the affected persons enrolled for the study. Same allele ratio was observed in case and control individuals for +331G/A SNP (Case: $\mathrm{F}=0.97$; Control: $\mathrm{F}=0.99$; Table 3). Therefore, a negative association of genotype and phenotype was observed for $+331 \mathrm{G} / \mathrm{A}$ mutation and cancer occurrence in our community.

We correlated the PROGINS polymorphisms and premenopause/menopause with a probability of getting breast cancer. No significant association with breast cancer development was observed between PROGINS SNP and pre-menopause/menopause (premenopause: $\mathrm{x} 2=1.015 ; \mathrm{df}=2 ; \mathrm{P}>0.05)$, menopause: $\mathrm{x} 2=2.821 ; \mathrm{df}=2 ; \mathrm{P}>0.05$; Table 4). Women with or without menopause and PROGINS polymorphisms are at similar risk for developing cancer. Cross tabulation studies to check the inference between $+331 \mathrm{G} / \mathrm{A}$ SNP and premenopause/menopause with breast cancer was also studied. The study showed that the PROGINS polymorphism did not have a significant association with disease susceptibility in the context of menopause. $(\mathrm{X} 2=1.563 ; \mathrm{df}=1 ; \mathrm{P}=0.219)$. The casecontrol study to check the association of breast cancer with $+331 \mathrm{G} / \mathrm{A}$ SNP in premenopausal females reported an inverse association $(\mathrm{X} 2=6.313 ; \mathrm{df}=2 ; \mathrm{P}>0.05$; Table 4). The incidence ratio of alleles of PROGINS studied were $70.7 \%(+/+)$, 
$26.0 \%(+/-)$ and $3.3 \%(-/-)$ in local community.

By making comparison of the allele incidence ratios of PROGINS SNP in global communities like Australia, England, Netherland, Brazil, Italy, and USA [11, 16-20], it was noticed that the percentage of PROGINS in Australia,
England, Netherlands and Italy is same as observed in present study, while high incidence rate was observed in case of Brazil $(80.5 \%)$. The percentages of three alleles of $+331 \mathrm{G} /$ A polymorphisms studied in local community of Pakistan were $96.3 \%$ $(+/+), 3.3 \%(+/-)$ and $0.5 \%(-/-) .($ Table 5).

Table 1. Frequencies of demographic factors in Pakistani population

\begin{tabular}{|c|c|c|c|c|c|}
\hline Characteristics & Category & Control $N=115$ & Case $\mathrm{N}=100$ & $P$ value & d.f. \\
\hline Age & $\begin{array}{l}15-25 \\
26-35 \\
36-45 \\
46-60 \\
60-70\end{array}$ & $\begin{array}{c}34(15.8 \%) \\
39(18.1 \%) \\
24(11.2 \%) \\
4(1.9 \%) \\
34(15.8 \%)\end{array}$ & $\begin{array}{c}1(0.46 \%) \\
19(8.8 \%) \\
48(22.3 \%) \\
12(5.60 \%) \\
1(0.46 \%)\end{array}$ & $0.000^{* * * *}$ & 4 \\
\hline Menopause & $\begin{array}{l}\text { Post } \\
\text { Pre- }\end{array}$ & $\begin{array}{c}18(8.4 \%) \\
97(43.7 \%)\end{array}$ & $\begin{array}{l}49(22.8 \%) \\
51(23.8 \%)\end{array}$ & $0.000^{* * *}$ & 1 \\
\hline Menopause Age & $\begin{array}{c}28-38 \\
39-48 \\
49-58 \\
\text { N/A }\end{array}$ & $\begin{array}{c}1(0.5 \%) \\
10(4.7 \%) \\
7(3.3 \%) \\
97(43.7 \%)\end{array}$ & $\begin{array}{c}6(2.8 \%) \\
34(15.8 \%) \\
8(3.7 \%) \\
52(24.1 \%)\end{array}$ & $0.000^{* * *}$ & 3 \\
\hline Marriage & $\begin{array}{l}\text { Yes } \\
\text { No }\end{array}$ & $\begin{array}{c}101(46.9 \%) \\
14(6.5 \%)\end{array}$ & $\begin{array}{c}97(43.7 \%) \\
3(1.4 \%) \\
\end{array}$ & $0.013^{*}$ & 1 \\
\hline Marriage Age & $\begin{array}{c}15-25 \\
26-35 \\
\text { N/A }\end{array}$ & $\begin{array}{c}91(42.3 \%) \\
9(4.2 \%) \\
15(6.9 \%)\end{array}$ & $\begin{array}{c}89(41.4 \%) \\
7(3.3 \%) \\
4(1.9 \%)\end{array}$ & $0.060^{\mathrm{ns}}$ & 2 \\
\hline Breast Cancer Age & $\begin{array}{c}26-35 \\
36-45 \\
46-55 \\
56-65 \\
\text { N/A }\end{array}$ & $\begin{array}{l}0 \\
0 \\
0 \\
0 \\
0\end{array}$ & $\begin{array}{c}26(12.1 \%) \\
44(20.5 \%) \\
22(10.2 \%) \\
8(3.7 \%) \\
0\end{array}$ & $0.000^{* * *}$ & 4 \\
\hline $\begin{array}{c}\text { History of Breast } \\
\text { Cancer }\end{array}$ & $\begin{array}{l}\text { Yes } \\
\text { No }\end{array}$ & $\begin{array}{c}0 \\
100\end{array}$ & $\begin{array}{c}16(7.4 \%) \\
84(39.1 \%)\end{array}$ & $0.000^{* * *}$ & 1 \\
\hline $\begin{array}{l}\text { Age at 1st } \\
\text { Pregnancy }\end{array}$ & $\begin{array}{c}15-25 \\
26-35 \\
\text { N/A }\end{array}$ & $\begin{array}{c}79(36.7 \%) \\
15(6.9 \%) \\
21(9.8 \%)\end{array}$ & $\begin{array}{c}71(33.0 \%) \\
16(7.4 \%) \\
13(6.0 \%)\end{array}$ & $0.522^{\mathrm{ns}}$ & 2 \\
\hline No of pregnancies & $\begin{array}{c}1-5 \\
6-10 \\
11-15 \\
\text { N/A }\end{array}$ & $\begin{array}{c}66(30.7 \%) \\
24(11.2 \%) \\
4(1.9 \%) \\
21(9.8 \%)\end{array}$ & $\begin{array}{c}53(24.7 \%) \\
32(14.9 \%) \\
2(0.9 \%) \\
13(6 \%)\end{array}$ & $0.252^{\mathrm{ns}}$ & 3 \\
\hline Breast feeding & $\begin{array}{l}\text { Yes } \\
\text { No }\end{array}$ & $\begin{array}{l}78(36.3 \%) \\
37(17.2 \%)\end{array}$ & $\begin{array}{l}82(38.1 \%) \\
37(17.2 \%)\end{array}$ & $0.019^{*}$ & 1 \\
\hline Breast feeding Age & $\begin{array}{c}15-25 \\
26-35 \\
36-45 \\
\text { N/A } \\
\end{array}$ & $\begin{array}{c}21(9.8 \%) \\
55(25.6 \%) \\
17(7.9 \%) \\
22(10.2 \%)\end{array}$ & $\begin{array}{c}8(3.7 \%) \\
52(24.1 \%) \\
24(11.2 \%) \\
16(7.4 \%)\end{array}$ & $0.071^{\mathrm{ns}}$ & 3 \\
\hline Smoking & $\begin{array}{l}\text { Yes } \\
\text { No }\end{array}$ & $\begin{array}{c}13(6.0 \%) \\
102(47.4 \%)\end{array}$ & $\begin{array}{l}4(1.9 \%) \\
96(96 \%)\end{array}$ & $0.074^{\mathrm{ns}}$ & 1 \\
\hline Pesticide Exposure & $\begin{array}{l}\text { Yes } \\
\text { No }\end{array}$ & $\begin{array}{l}34(15.8 \%) \\
81(37.7 \%)\end{array}$ & $\begin{array}{l}16(44.7 \%) \\
84(39.1 \%)\end{array}$ & $0.023^{*}$ & 1 \\
\hline
\end{tabular}




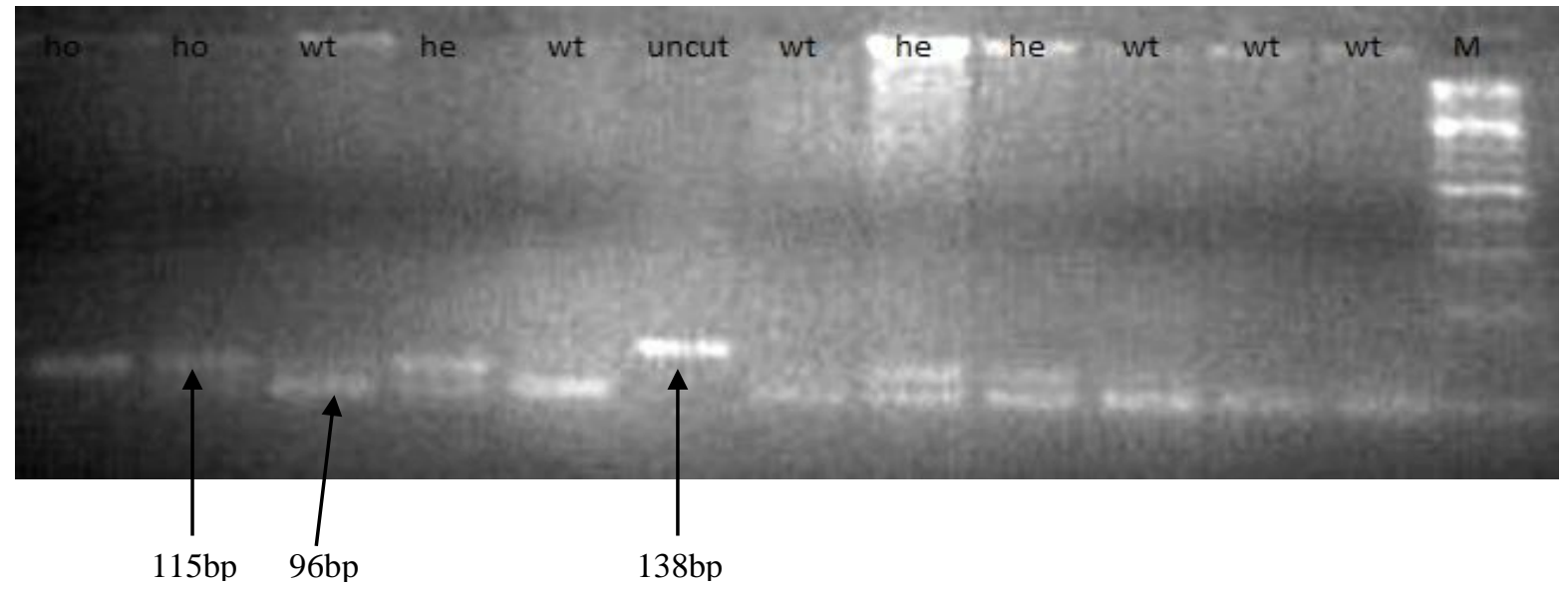

Figure 1. Gel electrophoresis for RFLP product of PROGINS. PROGINS wild type is shown in lanes $3,5,7,10,11 \& 12$; homozygous mutant in lanes $1 \& 2$; heterozygous in lanes $4,8 \& 9$ respectively. Uncut is given in lane 6 and 100bp ladder (lane $M$ )

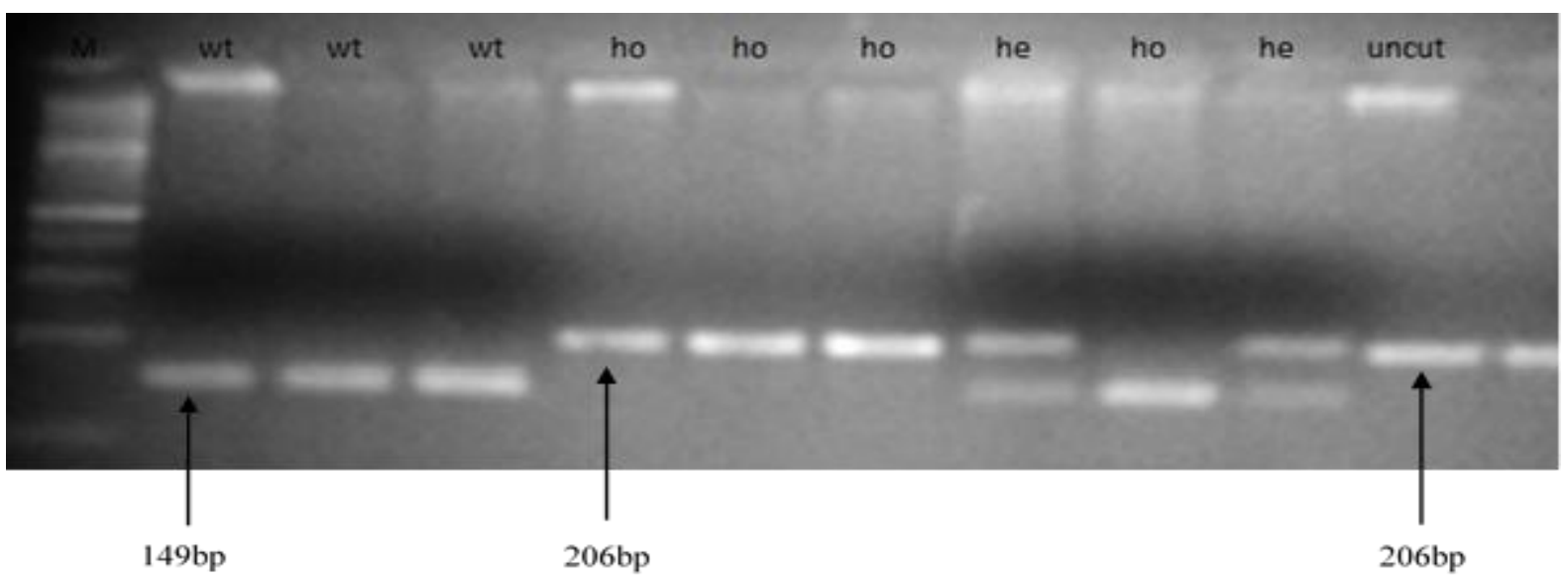

Figure 2. Gel electrophoresis for restriction product of $+331 G / A .+331 G / A$ wild type is shown in lanes 2, $3 \&$ \&; homozygous mutant in lanes 5, 6, $7 \&$ 9; heterozygous in lanes 8 $\& 10$ respectively. Uncut is given in last lane and $100 \mathrm{bp}$ ladder in lane $M$

Table 2. Logistic regression analysis of menopause and other variables

\begin{tabular}{|c|c|c|c|c|c|c|}
\hline \multirow[b]{2}{*}{ Menopause } & Parameters & Categories & B-test & T-test & d.f. & $P$ value \\
\hline & Present age & $\begin{array}{l}15-25 \\
26-35 \\
36-45 \\
46-60 \\
60-70\end{array}$ & $\begin{array}{c}-21.82 \\
-7.28 \\
-5.14 \\
-7.47 \\
-\end{array}$ & $\begin{array}{c}-11.3 \\
0 \\
0 \\
0 \\
-\end{array}$ & $\begin{array}{c}213 \\
213 \\
213 \\
213 \\
-\end{array}$ & $0.000^{* * * *}$ \\
\hline \multirow{3}{*}{ Pre-menopause } & B. feeding & $\begin{array}{l}\text { Yes } \\
\text { No }\end{array}$ & $\begin{array}{c}2.31 \\
0\end{array}$ & $\begin{array}{l}0 \\
-\end{array}$ & $\begin{array}{c}213 \\
-\end{array}$ & $0.021^{* *}$ \\
\hline & PROGINS & $\begin{array}{c}(+/+) \\
(+/-) \\
(-/-)\end{array}$ & $\begin{array}{c}3.32 \\
3.186 \\
0\end{array}$ & $\begin{array}{l}0 \\
0 \\
0\end{array}$ & $\begin{array}{c}213 \\
213 \\
-\end{array}$ & $0.60^{\mathrm{ns}}$ \\
\hline & $+331 G / A$ & $\begin{array}{l}\text { (GG) } \\
\text { (GA) } \\
\text { (AA) }\end{array}$ & $\begin{array}{c}-6.24 \\
0 \\
-\end{array}$ & $\begin{array}{l}0 \\
0 \\
0\end{array}$ & $\begin{array}{c}213 \\
- \\
213\end{array}$ & $0.045^{*}$ \\
\hline
\end{tabular}


Table 3. Genotype and allelic frequency of progins and +331 G/A

\begin{tabular}{|c|c|c|c|c|c|c|c|c|}
\hline \multicolumn{5}{|c|}{ PROGINS } & \multicolumn{4}{|c|}{$+331 G / A$} \\
\hline & $(+/+)$ & $(+/-)$ & $(-1-)$ & Sig. Test & GG & GA & $\mathbf{A A}$ & Sig. Test \\
\hline Control & $83(72.2 \%)$ & $27(23.5 \%)$ & $5(4.3 \%)$ & \multirow{2}{*}{$\begin{array}{c}X^{2}=1.6 \\
\text { d.f. }=2 \\
P=0.4^{\mathrm{ns}}\end{array}$} & $114(99 \%)$ & 0 & $\begin{array}{c}1 \\
(0.9 \%) \\
\end{array}$ & \multirow{2}{*}{$\begin{array}{c}X^{2}=9.1 \\
\text { d.f }=2 \\
P=0.004^{* *}\end{array}$} \\
\hline Case & $69(69 \%)$ & $29(29 \%)$ & $2(2 \%)$ & & $93(93 \%)$ & $7(7 \%)$ & 0 & \\
\hline
\end{tabular}

Table 4. Significance test of progins and $+331 G / A$ and menopause with breast carcinoma

\begin{tabular}{|c|c|c|c|c|c|c|}
\hline \multirow{2}{*}{ Genotype } & \multicolumn{3}{|c|}{ Pre-Menopause } & \multicolumn{3}{c|}{ Menopause } \\
\cline { 2 - 7 } & Control & Case & Sig. Test & Control & Case & Sig. Test \\
\hline Progin (+/+) & $70(32.56 \%)$ & $33(15.35 \%)$ & $\mathrm{X}^{2}=1.015$ & $13(6.05 \%)$ & $36(16.74 \%)$ & $\mathrm{X}^{2}=2.821$ \\
\hline Progin (+/-) & $23(10.7 \%)$ & $16(7.44 \%)$ & $\mathrm{df}=2$ & $4(1.86 \%)$ & $13(6.05 \%)$ & $\mathrm{df}=2$ \\
\hline Progin (-/-) & $4(1.86 \%)$ & $2(0.93 \%)$ & $P=0.605^{\mathrm{ns}}$ & $1(0.47 \%)$ & 0 & $P=0.253^{\mathrm{ns}}$ \\
\hline+ 331G/A (+/+) & $96(44.65 \%)$ & $48(22.32 \%)$ & $\mathrm{X}^{2}=6.313$ & $18(8.37 \%)$ & $45(20.93 \%)$ & $\mathrm{X}^{2}=1.563$ \\
\hline+ 331G/A (+/-) & 0 & $3(1.39 \%)$ & $\mathrm{df}=2$ & 0 & $4(1.86 \%)$ & $\mathrm{df}=1$ \\
\hline+ +331G/A (-/-) & $1(0.5 \%)$ & 0 & $P=0.045^{*}$ & 0 & 0 & $P=0.219^{\mathrm{ns}}$ \\
\hline
\end{tabular}

Table 5. Global distribution of frequencies of progesterone receptor

\begin{tabular}{|c|c|c|c|c|c|c|c|c|}
\hline \multirow{2}{*}{ Population } & \multirow{2}{*}{ No. } & \multicolumn{3}{|c|}{ PROGINS } & \multicolumn{3}{c|}{ +331G/A } & \multirow{2}{*}{ Reference } \\
\cline { 3 - 8 } & & $(+/+)$ & $(+/-)$ & $(-/-)$ & $(+/+)$ & $(+/-)$ & $(-/-)$ & \\
\hline Pakistan & 215 & 70.7 & 26.0 & 3.3 & 96.3 & 3.3 & 0.5 & Present study \\
\hline Australia & 175 & 70.2 & 26.95 & 2.8 & 89.1 & 10.9 & 10.9 & {$[16]$} \\
\hline Brazil & 303 & 80.5 & 18.25 & 2.5 & - & - & - & {$[17]$} \\
\hline Italy & 258 & 73.3 & 25.15 & 1.5 & & & & {$[18]$} \\
\hline Netherland & 546 & 73.1 & 24.4 & 2.6 & 89.0 & 9.0 & 2.1 & {$[19]$} \\
\hline USA & 987 & - & - & - & 89.0 & 10.9 & 0.7 & {$[20]$} \\
\hline
\end{tabular}

\section{Discussion}

Different factors contribute to a female's chances to develop breast tumor, including factors related to her hormonal status. Not only is estrogen essential for breast and ovarian tissues to develop, but progesterone is also important for differentiation and proliferation. As the menstrual cycle nears its end, progesterone is released from the ovaries to prepare the uterus for receiving the egg. When the egg has been fertilized, the progesterone hormone works to prevent further egg release. Because of this ability, it is also called the "pregnancy-supporting" hormone. Anyhow its clear function in the progression of a disease is not yet known. Currently, no authentic data is present for the function of these SNPs in local
Various studies of healthy and affected mammary tissues have produced contradictory findings, depicting that progesterone may either lead to enhancement, decline or no variation at all. PR receptor-bound hormones act as nuclear transcription factors, with multiple effects in addition to binding to PR receptors. There is no doubt that progesterone receptor SNPs cause PR expression, thereby disrupting hormonal homeostasis in the cells. Also described are the effects of these SNPs on the risk for benign and malignant gynecological anomalies among different populations throughout the world [21].

community. This study is one of the first to investigate the function of progesterone 
polymorphisms in breast cancer risk in the southern Punjab region. It was shown that progesterone did not affect cancer phenotype in a significant way and an inverse correlation was observed in Pakistani women when analyzing the relative susceptibility to breast cancer with $+331 \mathrm{G} / \mathrm{A}$ polymorphism. The new results concur with those found in previous studies performed in populations in Germany and Ireland that indicated that the PROGINS polymorphism did not affect the chance of breast cancer progression. The PROGINS polymorphism was not found to be associated with breast cancer in other casecontrol studies [16, 22].

Evaluation of PROGINS mutations on the Nurses' also indicated that PROGINS alleles have no significant association with memory tumor development. The function of PROGINS polymorphism have contrasting findings about breast cancer development. There has been research suggesting a positive relationship between the 2 nd progesterone variant $+331 \mathrm{G} / \mathrm{A}$ and either mammary, endometrial, or ovarian tumors in multiple populations. Some studies did not support the hypothesis of role of $+331 \mathrm{G} / \mathrm{A}$ variant in cancer development. One study reported that two functional PGR polymorphisms in the Australian population were nonsignificantly associated with the development of breast cancer [20]. In the same way, four variants of this gene (+44C/T, +331G/A, Gly393Gly, Val660Leu) were analyzed showing no significant link between the SNPs and the development of ovarian and endometrial tumor $[23,24]$.

According to our study results, crosstabulation test between $+331 \mathrm{G} / \mathrm{A}$ and the PROGINS genotypes revealed that some demographic factors had a strong influence on breast cancer incidences among the Pakistani population, such as family history of cancer and menopause. Various reports are present to support the association of family history with disease development. It has been shown that in women who had their mother or sister diagnosed with breast cancer when they were young, their risk of developing breast cancer remains elevated. A systematic review about the risk factors of breast cancer particularly family history was published. The results were consistent for various study results showing more chances of evolving breast cancer with family history [25].

Female reproductive factors are responsible for about $40-50 \%$ of breast cancer risks among women. Hormonal conditions including early menarche and late menopause, have high chance of cancer and according to the studies; women with natural menopause had greater the risk of breast cancer. We can explain how cancer susceptibility is related to these risk factors by considering hormone levels, menstrual periods, irregular cycles and induction of cell differentiation [11].

\section{Conclusion}

It can be concluded from all of the foregoing that PROGINS polymorphism does not have any relation to breast tumor occurrences in our population., while $+331 \mathrm{G} / \mathrm{A}$ mutation is conversely related to breast tumor and The situation is exacerbated even further by hormonal changes during menopause, resulting in an increased risk of breast cancer with the PROGINS and +331G/A gene mutations. But there was lack of any link with other variables like marital status, conception age, number of gravidities, breastfeeding, age at last breastfeeding, and smoking.

The study was performed with small number of samples consisting of one-year data due to shortage of funds. Increasing the sample size will assist in analyzing these polymorphisms more effectively. All data were based on self-reports of women who did not have a confirmed history of breast cancer and whose memory of the exact age of menopause was not reliable. Further studies are obviously needed, including age, gender, and known polymorphisms of the progesterone gene, along with other hormones in breast cancer pathways, to pinpoint the role of the 
progesterone gene in the development of breast cancer in the Pakistani population.

\section{Authors' contributions}

Conceived and designed the experiments: RS Shaikh, Performed the experiments: $S$ Sadia, Analyzed the data: N Tariq, Contributed materials/ analysis/ tools: RS Shaikh, Wrote the paper: $\mathrm{N}$ Tariq \& $\mathrm{T}$ Kausar.

\section{Acknowledgements}

We like to thank Ahmed Ijaz Masood, the head of the radiotherapy unit of Nishtar Hospital, Multan, Pakistan, for enrolment of cancer patients. The authors thank all the participants of the study. We thank the laboratory personnel of Institute of Molecular Biology and Biotechnology for technical assistance.

\section{References}

1. Bray F et al. (2018). Global cancer statistics 2018: GLOBOCAN estimates of incidence and mortality worldwide for 36 cancers in 185 countries. $C A$ Cancer J Clin 68(6): 394-424.

2. Venturi $S$ (2001). Is there a role for iodine in breast diseases. The Breast 10(5): 379-382.

3. Youlden DR et al. (2014). Incidence and mortality of female breast cancer in the Asia-Pacific region. Cancer Biol Med 11(2): 101-15.

4. Lydon JP et al. (1995). Mice lacking progesterone receptor exhibit pleiotropic reproductive abnormalities. Genes Dev 9(18): 2266-2278.

5. Westberg L et al. (2004). Polymorphisms in oestrogen and progesterone receptor genes: possible influence on prolactin levels in women. Clin Endocrinol 61(2): 216-223.

6. De Vivo I et al. (2002). A functional polymorphism in the promoter of the progesterone receptor gene associated with endometrial cancer risk. Proc Natl Acad Sci 99(19): 12263-12268.

7. Spurdle AB et al. (2001). No significant association between progesterone receptor exon 4 Val660Leu G/T polymorphism and risk of ovarian cancer. J Carcinog 22(5): 717-721.
8. Donaldson CJ et al. (2002). PROGINS Alu insertion and human genomic diversity. Mutat Res-Fund Mol M 501(1-2): 137-141.

9. Wang-Gohrke S et al. (2000). Progesterone receptor gene polymorphism is associated with decreased risk for breast cancer by age 50. Cancer $\operatorname{Re}$ 60(9): 2348-2350.

10. Fabjani G et al. (2002). Human progesterone receptor gene polymorphism PROGINS and risk for breast cancer in Austrian women. Breast Cancer Res Treat 72(2): 31-137.

11. Lattuada D et al. (2004). Genetics of endometriosis: a role for the progesterone receptor gene polymorphism PROGINS? Clin Endocrinol 61(2): 190-194.

12. Tong D et al. (2001). Analysis of the human progesterone receptor gene polymorphism progins in Austrian ovarian carcinoma patients. Int $J$ Cancer 95(6): 394-397.

13. Feigelson HS et al. (2004). No association between the progesterone receptor gene+ $331 \mathrm{G} / \mathrm{A}$ polymorphism and breast cancer. Cancer Epidemiol Biomark Prev 13(6): 1084-1085.

14. Huggins, GS et al. (2006). GATA5 activation of the progesterone receptor gene promoter in breast cancer cells is influenced by the+ $331 \mathrm{G} / \mathrm{A}$ polymorphism. Cancer Res 66(3): 1384-1390.

15. Grimberg J et al. (1989). A simple and efficient non-organic procedure for the isolation of genomic DNA from blood. Nucleic Acids Res 17(20): 8390.

16. Johnatty SE et al. (2008). Progesterone receptor polymorphisms and risk of breast cancer: results from two Australian breast cancer studies. Breast Cancer Res Treat 109(1): 1-99.

17. Junqueira MG et al. (2007). Progesterone receptor (PROGINS) polymorphism and the risk of endometrial cancer development. Int $J$ Gynecol Cancer 17(1): 229-232. 
18. Lattuada D et al. (2004). Genetics of endometriosis: a role for the progesterone receptor gene polymorphism PROGINS. Clinical Endocrinol 61(2): 190-194.

19. Romano A et al. (2006). Two functionally relevant polymorphisms in the human progesterone receptor gene (+ 331 G/A and progins) and the predisposition for breast and/or ovarian cancer. Gynecol Oncol 101(2): 287295.

20. Terry KL et al. (2005). Genetic variation in the progesterone receptor gene and ovarian cancer risk. Am J Epidemiol 161(5): 442-451.

21. De Vivo I et al. (2003). A functional polymorphism in the progesterone receptor gene is associated with an increase in breast cancer risk. Cancer Res 63(17): 5236-5238.

22. Pearce A et al. (2018). Productivity losses due to premature mortality from cancer in Brazil, Russia, India, China, and South Africa (BRICS): A population-based comparison. Cancer Epidemiol 53: 27-34.

23. Dossus L et al. (2006). No association between progesterone receptor gene+ 331G/A polymorphism and endometrial cancer. Cancer Epidemiol Biomark Prev 15(7): 1415-1416.

24. Lahmann PH et al. (2004). Body size and breast cancer risk: findings from the European Prospective Investigation into Cancer and Nutrition (EPIC). Int J Cancer 111(5): 762-771.

25. Russo J et al. (2005). The protective role of pregnancy in breast cancer. Breast Cancer Res 7(3): 131. 